\title{
Induction of puberty in Bos indicus heifers in the western Amazon region
}

\section{Indução da puberdade em novilhas Bos indicus na região oeste da Amazônia}

\author{
Suellen Miguez González ${ }^{1 *}$; Igor Emanuel Gomes Assunção²; James Duarte; \\ Carlos Henrique Andrade Oliveira ${ }^{2}$; Tales André Guedes ${ }^{2}$; Fábio Morotti ${ }^{1}$; \\ Marcelo Marcondes Seneda ${ }^{3 *}$; Evelyn Rabelo Andrade ${ }^{4}$
}

\section{Highlights:}

Nelore heifers from the western Amazon responded to puberty induction after the fourth use of CIDR and injectable P4. More Nelore heifers became pregnant after induction of puberty with injectable P4.

There was a $42 \%$ economy from the use of injectable $\mathrm{P} 4$ in the puberty induction protocol.

\begin{abstract}
The objective of this study was to evaluate the efficiency and cost of two distinct hormonal protocols for induction of puberty in Bos indicus heifers in the western Amazon region. Nelore prepubertal heifers (n $=127)$ aged 20 to 24 months $(21 \pm 0.3$ months $)$ and weighing 300 to $340 \mathrm{~kg}(318 \pm 7 \mathrm{~kg})$ were submitted to two distinct protocols for induction of cyclicity. Females were previously submitted to two ovarian ultrasound examinations (12-day interval) to verify the absence of the corpus luteum (CL). Then, the heifers were divided into two experimental groups: G-CIDR/EC $(n=54)$ and G-P4/EC $(n=73)$. The G-CIDR/EC group utilized a CIDR ${ }^{\circledR}$ for 12 days and on the day of its withdrawal, $0.6 \mathrm{mg}$ of estradiol cypionate (IM) was administered. The G-P4/EC group received $150 \mathrm{mg}$ of injectable progesterone (IM) and one injection of $0.6 \mathrm{mg}$ EC 12 days after the progesterone injection. Twelve days after the end of the hormonal protocols, the heifers were submitted to another ultrasound evaluation for identification of cyclicity (ovulatory follicle or CL). These females were then submitted to a conventional protocol of synchronization of ovulation for timed artificial insemination (TAI). Only heifers responsive to puberty induction (G-CIDR/EC $(n=30)$ and G-P4/EC $(n=51))$ were included in the TAI protocol. After seven days of insemination, both groups were exposed to natural breeding. In addition, an economic analysis was performed to evaluate cyclicity induction, the TAI protocol, and pregnancy in both groups. The G-CIDR/EC group showed 81.48\% (44/54) of females responsive to induction of cyclicity (presence of $\mathrm{CL})$ while the G-P4/EC group obtained $86.3 \%(63 / 73 ; \mathrm{p}=0.463)$. Regarding the conception rate to TAI and to bull (natural breeding), the G-CIDR/EC group displayed $43.33 \%(13 / 30)$ and $33.33 \%(10 / 30)$, respectively, and the G-P4/EC group exhibited $54.9 \%$ (28/51) and 39.22\% (20/51), respectively. The overall pregnancy rate (TAI+Bull) was $76.67 \%$ (23/30) in the G-CIDR/EC group compared to $94.12 \%$ $(48 / 51 ; \mathrm{P}=0.023)$ in the G-P4/EC group. The cost of the hormonal protocol to cyclicity induction resulted in an economy of $42.8 \%$ for injectable $\mathrm{P} 4$ compared to the intravaginal P4 group. In addition,
\end{abstract}

' Laboratório de Biotecnologia da Reprodução Animal, Universidade Estadual de Londrina, UEL, Londrina, PR, Brasil. E-mail: suellenmgonzalez@gmail.com; fabiomorotti@uel.br

2 Discentes do Curso de Graduação em Medicina Veterinária, Universidade Federal de Rondônia, UNIR, Rolim de Moura, RO, Brasil. E-mail: igorgomes.medvet@hotmail.com; james.duarte@hotmail.com; carlosh.vha_hotmail.com; tales_guedes@ hotmail.com

3 Prof. Dr., Programa de Pós-Graduação em Ciência Animal, Departamento de Clínicas Veterinárias, UEL, Londrina, PR, Brasil. E-mail:mseneda@uel.br

${ }^{4}$ Prof $^{a}$ Dr $^{\mathrm{a}}$, Curso de Graduação em Medicina Veterinária, UNIR, Rolim de Moura, RO, Brasil. E-mail: evelyn.andrade@unir.br

* Author for correspondence 
the final cost of cyclic induction associated with TAI was 34\% lower in the G-P4/EC group compared to the G-CIDR/EC group. We concluded that both cycling induction protocols were efficient in Bos indicus heifers from the western Amazon. However, injectable P4 provided a higher conception rate and lower pregnancy cost at the end of the reproductive season.

Key words: Bovine. Female. Progesterone. Cyclicity. Ovary.

\section{Resumo}

O objetivo deste estudo foi avaliar a eficiência e o custo de dois protocolos hormonais distintos para indução da puberdade em novilhas Bos indicus na região oeste da Amazônia. Novilhas pré-púberes Nelore $(\mathrm{n}=127)$ com idades entre 20 a 24 meses $(21 \pm 0,3$ meses $)$ e peso de 300 a $340 \mathrm{~kg}(318 \pm 7 \mathrm{~kg})$ foram submetidas a dois protocolos distintos para indução de ciclicidade. As fêmeas foram submetidas previamente a dois exames ultrassonográficos dos ovários (intervalo de 12 dias) para verificar a ausência do corpo lúteo (CL). Em seguida, as novilhas foram divididas em dois grupos experimentais: G-CIDR / EC $(\mathrm{n}=54)$ e G-P4 / EC $(\mathrm{n}=73)$. O grupo G-CIDR / EC utilizou um CIDR ${ }^{\circledR}$ por 12 dias e no dia de sua retirada, foram administrados $0,6 \mathrm{mg}$ de cipionato de estradiol (IM). O grupo G-P4 / EC recebeu $150 \mathrm{mg}$ de progesterona injetável (IM) e após 12 dias da administração de progesterona, administrouse $0,6 \mathrm{mg}$ de EC. Doze dias após o término dos protocolos hormonais, as novilhas foram submetidas a outra avaliação ultrassonográfica para identificação da ciclicidade (folículo ovulatório ou CL). Essas fêmeas foram submetidas a um protocolo convencional de sincronização da ovulação para inseminação artificial em tempo fixo (IATF). Apenas novilhas responsivas à indução da puberdade (G-CIDR / EC $(\mathrm{n}=30)$ e G-P4 / EC $(\mathrm{n}=51))$ foram incluídas no protocolo de IATF. Após sete dias da inseminação, ambos os grupos foram expostos à monta natural. Além disso, uma análise econômica foi realizada para avaliar a indução da ciclicidade, o protocolo IATF e a prenhez nos dois grupos. O grupo G-CIDR / CE apresentou $81,48 \%$ (44/54) de fêmeas responsivas à indução da ciclicidade (presença de CL) enquanto o grupo G-P4 / EC obteve 86,3\% (63/73; p = 0,463). Em relação à taxa de concepção de IATF e de touro (monta natural), o grupo G-CIDR / CE apresentou 43,33\% (13/30) e 33,33\% (10/30), respectivamente, e o grupo G-P4 / EC exibiu 54,9 \% (28/51) e 39,22\% (20/51), respectivamente. A taxa geral de prenhez (IATF + Touro) foi de 76,67\% (23/30) no grupo G-CIDR / CE em comparação com 94,12\% (48/51; $\mathrm{P}=0,023)$ no grupo G-P4 / CE. O custo do protocolo hormonal para indução da ciclicidade resultou em uma economia de $42,8 \%$ para P4 injetável em comparação ao grupo com dispositivo intravaginal de P4. Além disso, o custo final da indução cíclica associada a IATF foi 34\% menor no grupo G-P4 / EC em comparação ao grupo G-CIDR / EC. Concluímos que ambos os protocolos de indução de ciclicidade foram eficientes em novilhas Bos indicus da Amazônia ocidental. No entanto, o P4 injetável proporcionou maior taxa de concepção e menor custo de prenhez no final da estação reprodutiva.

Palavras-chave: Bovino. Fêmea. Progesterona. Ciclicidade. Ovário.

\section{Introduction}

The western Amazon region is located in the geographical center of the Amazon and is composed of the states of Acre, Amazonas, Roraima, and Rondônia, which together account for more than 19 million head of cattle. Brazilian livestock is known worldwide for its high productive potential, containing the largest commercial cattle herd in the world, with about 218.23 million animals. Of this amount, $43 \%$ are cows and $10 \%$ are two- to threeyear old heifers (Instituto Brasileiro de Geografia e
Estatistica [IBGE], 2017); in addition, among the zebu breeds, the Nelore is preferred by the cattle breeders of this region; however, information about its reproductive performance is limited in this environment (Azevêdo, Rocha, Jobim, Mattos, \& Gregory, 2007).

It is known that the occurrence of reproductive failures can significantly affect the profitability of production systems. In this context, age at puberty has been considered one of the most relevant factors for the productive life of the future matrix (Funston, 
Musgrave, Meyer, \& Larson, 2012). In Brazil, the age at puberty of Bos indicus females is estimated at 22 to 36 months, projecting the age at first calving to 44 to 48 months (Nogueira, 2004). Late onset of reproductive age can significantly compromise the reproductive longevity of the female, considering the average life span of cows in Brazil is estimated at 120 months (Melo \& Queiroz, 2011).

The life of the beef cow can go beyond 12 years; however, after 10 years of age, milk production declines and the animal starts to wean lighter calves. Considering 4 years as the average age of first calving and discarding at 10 years of age, the beef cows in Brazil produce an average of 4-5 calves (Melo \& Queiroz, 2011). Therefore, the long breeding period of the calves until they reach sexual maturity, which is associated with the short period of useful reproductive life of a matrix, emphasizes the fact that the rearing system in Brazil is challenging, and therefore reinforces the need for investment in techniques and strategies that improve the livestock system.

Offspring management in a farm requires a pubertal heifer prior to the start of the breeding season due to the restricted period of coverage. Therefore, females who reach puberty early have greater reproductive performance and a greater probability of return cyclicity after the first calving (Funston et al., 2012). Thus, heifers that have a corpus luteum at the beginning of the breeding season have a higher pregnancy rate for timed artificial insemination (TAI) compared to acyclic heifers (Sá et al., 2012).

The use of hormonal protocols to induce and synchronize estrus in heifers can be a tool to add greater reproductive efficiency in cattle (Azevêdo et al., 2007). Therefore, to increase the number of cyclic heifers at the beginning of the breeding season, several hormonal treatments using a progesterone (P4) device and an estrogen source were developed to induce the first ovulation of young females. Treatment with $\mathrm{P} 4$ and estrogen may modulate the functioning of the hypothalamus- pituitary axis, increasing gonadotropin secretion and inducing puberty (Sá et al., 2015).

Due to the cost of intravaginal P4 devices, their reuse in TAI programs aims to achieve better economic efficiency. Baruselli et al. (2006) observed that this practice can reduce the costs of estrus induction and ovulation synchronization programs in cattle, as well as contribute to expressive fertility results. However, in both cows and heifers, the reuse of $\mathrm{P} 4$ devices have shown varied results depending on the breed, individual response, nutritional status, diet, and adopted hormonal combination (Pinto, Silva, Mota, \& Alberton, 2009).

Conversely, the use of injectable $\mathrm{P} 4$ in synchronization protocols has been related to low cost, easy management of animals, and hygienic benefits (Morotti, Campos, Oliveira, \& Seneda, 2013a; Morotti, Campos, \& Seneda, 2013b; Campos, Morotti, Bergamo, Costa, \& Seneda, 2016a; Campos, Morotti, Costa, Bergamo, \& Seneda, 2016b). For TAI programs, these benefits provide a reduction in the risk of health problems associated with intravaginal devices, such as loss of the device and the occurrence of vaginitis and vulvovaginitis (Morotti et al., 2013a,b, 2018). Considering the sanitary particularity of nulliparous females, this P4 source represents an interesting strategy for reproductive programs in heifers.

Therefore, the present study aimed to perform a reproductive and economic analysis of puberty induction protocols in Bos indicus heifers from the western Amazon region, using either an intravaginal P4 device or injectable P4.

\section{Material and Methods}

This study was conducted in accordance with the ethical standards and principles in animal experimentation adopted by the Brazilian College of Experimentation (COBEA) and was approved by the Animal Use Ethics Commission (CEUA) of the Faculty of Biomedical Sciences of Cacoal FACIMED under protocol number 011/2017. 


\section{Location, animals, and management}

This study was carried out during the breeding season for beef cattle in South America at a latitude of $09^{\circ} 35^{\prime} 18$ 'S and longitude $67^{\circ} 31^{\prime} 57^{\prime}$ " $\mathrm{W}$, at a commercial farm located in the municipality of Porto do Acre, state of Acre, Brazil. The climate in this region is tropical, with an average temperature of $26.1^{\circ} \mathrm{C}$ and an average annual rainfall of $1951 \mathrm{~mm}$.

Pre-pubertal Nelore (Bos indicus) heifers $(\mathrm{n}=$ 127) aged 20 to 24 months ( $21 \pm 0.3$ months) and weighing 300 to $340 \mathrm{Kg}(318 \pm 7 \mathrm{~kg})$ were submitted to two different protocols for cyclicity induction. All females were previously evaluated by two ovarian ultrasound examinations (11-day intervals) to determine the absence of the corpus luteum (CL). Afterward, the heifers were divided into two experimental groups: the intravaginal $\mathrm{P} 4$ device (G-CIDR/EC; $\mathrm{n}=54)$ group and the injectable $\mathrm{P} 4$ group (G-P4/EC; $n=73)$.

The G-CIDR/EC group utilized an intravaginal P4 device (4th use; CIDR ${ }^{\circledR}$, Zoetis Animal Health, São Paulo, Brazil) for 12 days, and on the day of withdrawal, $0.6 \mathrm{mg}$ of estradiol cypionate (EC, $\mathrm{ECP}^{\circledR}$, Zoetis Animal Health, São Paulo, SP, Brazil) was applied IM. G-P4/EC, $150 \mathrm{mg}$ of injectable P4 (IM, Sincrogest ${ }^{\mathbb{Q}}$, Ouro Fino, Cravinhos, Brazil), was applied IM and 12 days later the animals received $0.6 \mathrm{mg}$ of $\mathrm{EC}$, IM.

Twelve days after the end of the hormonal protocols, ultrasonographic evaluations (SonoScape, DOMED-Dominium Medical, Valinhos, Brazil) were performed to identify cyclicity (presence of CL) and the presence of the dominant follicle. Subsequently, only the cyclic heifers were submitted to ovulation synchronization for TAI, which included 30 females for the G-CIDR/EC group and 51 females in the G-P4/EC group. Thus, 7 days later, both groups were exposed to bulls of repass, which remained with the heifers for 60 days until the end of the breeding season.

Pregnancy diagnosis of all females was performed 76 days after TAI by B-mode ultrasonography
(SonoScape, DOMED-Dominium Medical) using a linear transducer with a frequency of $7.5 \mathrm{MHz}$. Each pregnancy was classified from TAI or bulls of repass by estimating the age of the conceptus.

\section{Economic indexes}

The economic indexes were calculated using the cost of each hormone involved in the protocol for inducing puberty and the cost of pregnancy by TAI, considering the values per animal and herd. For TAI cost, semen dose and veterinary labor per animal were also considered. This evaluation was performed for both groups, in which the adopted values followed the estimate adopted for the western Amazon region.

\section{Statistical analysis}

The effect of the P4 source (intravaginal device $v s$. injectable) on the cyclicity and conception rate of heifers was analyzed by the binary logistic regression model, including the main effect of hormonal treatment as a fixed effect and all other sources of variation as covariates of the model. For descriptive analysis, qualitative data are presented as a percentage $(\%)$. All statistical analyses were performed using Minitab $^{\circledR}$ statistical software version 18.1. The adopted significance level was $5 \%$.

\section{Results and Discussion}

Pre-pubertal heifers treated with either an intravaginal P4 device or injectable P4 obtained similar results in the rate of cyclicity induction (Figure 1). The conception rate to TAI and after natural breeding (bulls) was similar $(\mathrm{P}>0.05)$ between the G-CIDR/EC and G-P4/EC groups. However, the group in which cyclic induction was induced with injectable P4 resulted in a higher conception rate $(\mathrm{P}<0.05)$ at the end of the reproductive season (Figure 2 ). 


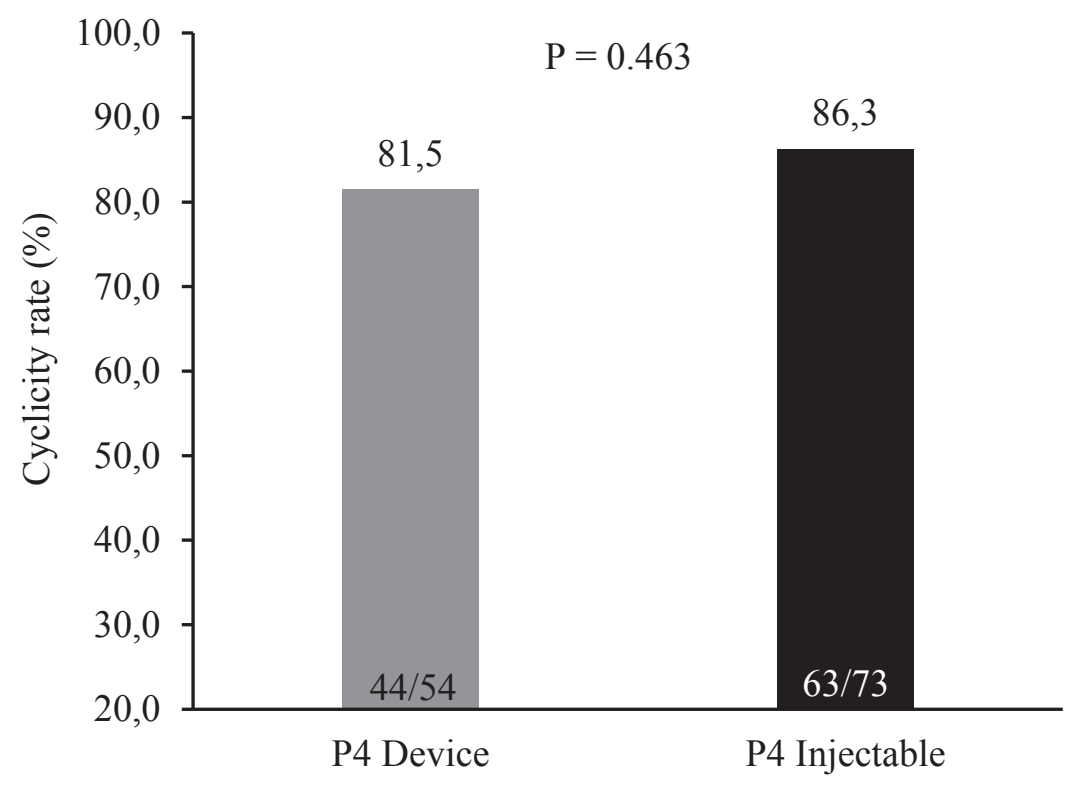

Figure 1. Cyclicity rate in prepubertal Nelore (Bos indicus) heifers following treatment for cyclicity induction with an intravaginal progesterone (P4) device + estradiol cypionate $(\mathrm{EC})$ or injectable $\mathrm{P} 4+\mathrm{EC}$ in the western Amazon region.

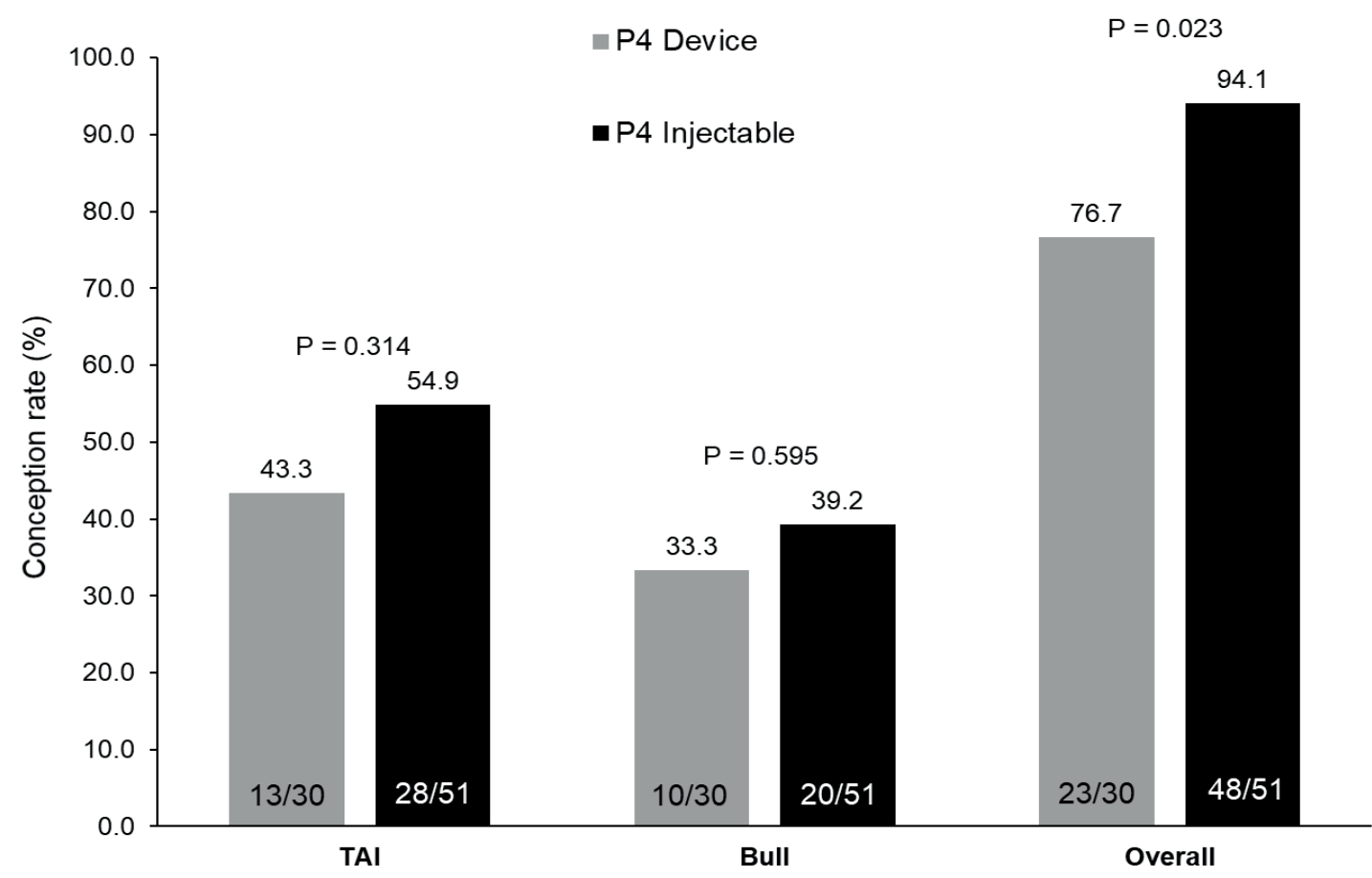

Figure 2. Conception rate after timed artificial insemination (TAI) or natural breeding with bulls of repass (return to heat) and at the end of the breeding season in Nelore (Bos indicus) heifers after induction of puberty with intravaginal progesterone (P4) + estradiol cypionate (EC) or injectable P4 + EC in the Western Amazon. 
In this context, the present study revealed the efficacy of cyclicity induction in prepubertal Nelore heifers treated with either an intravaginal P4 device or injectable P4. Our results were consistent with the results of Lima, Lemes, Martins and Madureira (2017) and Lemes et al. (2016), who highlighted the similarity of the pregnancy rate between protocols with injectable and intravaginal P4 use for females of the same category and breed. In addition, the plasma concentration was similar in Nelore heifers synchronized with either injectable P4 or an intravaginal P4 device (Felisbino-Neto et al., 2017), justifying the responsiveness to the induction protocol.

The present study tested $4^{\text {th }}$ use intravaginal P4 devices and achieved an efficient response for inducing puberty. Similarly, Ferreira, Andrade, Sonnewend, Silva and Mello (2016) and FelisbinoNeto et al. (2016) investigated cyclicity induction protocols using $3^{\text {rd }}$ or $4^{\text {th }}$ use intravaginal P4 devices compared to injectable $\mathrm{P} 4$, and also showed a positive result in $\mathrm{P} 4$ device reuse. In addition, regarding the induction of puberty in Nelore heifers using $1^{\text {st }}$ and $3^{\text {rd }}$ use CIDR, Claro et al. (2010) concluded that the reuse of the intravaginal device provided a higher pregnancy rate in this animal category. However, the conception rate to TAI was similar between groups in the present study, although heifers from P4-induced puberty induction resulted in a higher conception rate at the end of the breeding season (TAI + natural breeding).

Regardless of the hormonal presentation form, exogenous administration of $\mathrm{P} 4$ provides an acute effect that inhibits estradiol receptors in various tissues (Hseuh, Peck, \& Clark, 1976; Pavlik \& Coulson, 1976). Therefore, it is suggested that the expression of hypothalamic estradiol receptors decreases when prepubertal heifers receive exogenous P4 treatment, thus reducing negative feedback from estradiol on LH secretion (Day \& Anderson, 1998). This fact justifies the satisfactory response of the protocols proposed in our study.
For estrous cycle control, the most commonly used treatment includes the insertion of $\mathrm{P} 4$ devices ith their release for 5-10 days, maintaining plasma concentrations during this period (Baruselli, Reis, Marques, Nasser, \& Bó, 2004). High levels of P4 are necessary to block estrus manifestation and suppress the endogenous LH peak (Kinder, Kojima, Bergfeld, Wehrman, \& Fike, 1996), preventing ovulation but maintaining the growth and maturation of the dominant follicle (Rhodes, Burke, Clark, Day, \& MacMillan, 2002).

In this context, the use of an injectable P4 source has become an interesting pharmacological strategy to control the estrous cycle, bringing with it several potential advantages. Parenteral administration is a practical method because of the greater flexibility when used on a large scale. The injectable form of P4 comes at a lower cost due to the lack of silicone and other materials used in the manufacture of devices and implants. In addition, it provides a reduction in the risk of sanitary problems associated with the use of intravaginal devices, such as the occurrence of vaginitis and vulvovaginitis (Morotti et al., 2013a,b, 2018), especially in heifers. Furthermore, this P4 source may result in animal welfare improvements by avoiding vaginal/vulvar discomfort caused by the rod of the device.

Studies involving the effects of injectable P4 on estrous cycle control are limited (Ulberg \& Lindley, 1960; Fike et al., 1999). Two studies investigated the ovarian follicular dynamics of Bos indicus (Nelore) cows, in which ovulation was synchronized using injectable $\mathrm{P} 4$ versus an intravaginal device (Morotti et al., 2013a,b) and similarities were observed in the follicular characteristics of both groups. However, the injectable P4 for TAI provided lower pregnancy rates compared to protocols with a P4 device (Morotti et al., 2013b; Campos et al., 2016a,b), possibly due to residual P4 concentrations compromising the ovulation process at the time of insemination. 
In another aspect, the present study is of great importance because it is one of the few studies conducted in the Western Amazon region. This technical efficiency can certainly contribute to the productive system of this region, which in recent years has shown great importance in the Brazilian livestock community (Dias \& Andrade, 2006). In addition, it is noteworthy that injectable $\mathrm{P} 4$ represents an efficient, cost-effective alternative to induce cyclicity in prepubertal heifers, contributing to greater economic autonomy of the livestock system.
Regarding the proposed economic analysis (Table 1), the cost of the hormonal protocol to cyclicity induction resulted in an economy of $42.8 \%$ for injectable $\mathrm{P} 4$ compared to the intravaginal $\mathrm{P} 4$ group. The cost of conception to TAI was also lower for the injectable $\mathrm{P} 4$ group ( $\mathrm{R} \$ 122.62)$ compared to the intravaginal device group ( $\mathrm{R} \$ 184.46)$, because a larger number of pregnant females were found in the G-P4/EC group. In addition, the final cost of cyclic induction associated with TAI was 34\% lower in the G-P4/EC group compared to the G-CIDR/EC group.

Table 1

Costs related to puberty induction protocols and timed artificial insemination (TAI) program in Nelore (Bos indicus) heifers treated with either an intravaginal progesterone (P4) device + estradiol cypionate (EC) or injectable P4 + EC

\begin{tabular}{llcc}
\hline & & \multicolumn{2}{c}{ Protocol R\$ } \\
\cline { 3 - 4 } & & CIDR $^{\circledR} / \mathrm{EC}$ & P4 Injectable/EC \\
\hline \multirow{5}{*}{ Induction Cost } & 7.24 & 4.16 \\
& Progesterone (P4) ${ }^{1}$ & 0.57 & 0.57 \\
& Estradiol Cypionate (EC) & 7.81 & 4.73 \\
& Per animal & $421.74(\mathrm{n}=54)$ & $345.29(\mathrm{n}=73)$ \\
& Per group & $9.58(\mathrm{n}=44)$ & $5.48(\mathrm{n}=63)$ \\
& Per cyclic female & 16.50 & 16.50 \\
& Protocol per animal & 18.00 & 18.00 \\
\multirow{3}{*}{ TAI Cost } & Semen dose per animal & 20.00 & 20.00 \\
& Labor per animal & 54.50 & 54.50 \\
& Total TAI per animal & $2398.00(\mathrm{n}=44)$ & $3433.50(\mathrm{n}=63)$ \\
& Total TAI per group & $184.46(\mathrm{n}=13)$ & $122.62(\mathrm{n}=28)$ \\
\hline Final Cost & Total TAI per pregnancy & 194.04 & 128.10 \\
\hline
\end{tabular}

1 - Estimated cost per device use or per injectable P4 dose.

In the present study, injectable P4 was used only for puberty induction and not for TAI. Then, to cyclicity induction, there was no need for such precise control for circulating progesterone fall. Finally, similar to previous studies that have shown several positive aspects of injectable P4 (Morotti et al., 2013a,b; Campos et al., 2016a,b; Morotti et al., 2018), the present study also revealed that injectable P4 is efficient, low cost, and very promising for use in puberty induction programs in heifers.

\section{Conclusion}

Hormonal protocols with either injectable $\mathrm{P} 4$ or an intravaginal $\mathrm{P} 4$ device were efficient in inducing the cyclicity of prepubertal Nelore (Bos indicus) heifers in the western Amazon region. However, heifers with cyclicity induced by injectable P4 resulted in a higher conception rate at the end of the breeding season and a lower final cost of puberty induction and pregnancy. 


\section{Acknowledgment}

This study was supported by the Foundation to Support the Development of Scientific Actions and Technological and the Research of the State of Rondônia (FAPERO).

\section{References}

Azevêdo, D. M., Rocha, D. C., Jobim, M. I. M., Mattos, R. C., \& Gregory, R. M. (2007). Efeito da sincronização e da indução de estros em novilhas sobre a prenhez e o índice de repetição de crias na segunda estação reprodutiva. Ciência Rural, 37(1), 201-2015. doi: 10.1590/S0103-84782007000100032

Baruselli, O. S., Ayres, H., Souza, A. H., Martins, C. M., Gimenes, L. U., \& Torres, J. R. S., Jr. (2006). Impacto da IATF na eficiência reprodutiva em bovinos de corte. Anais do Simpósio Internacional de Reprodução Animal Aplicada, Londrina, PR, Brasil, 2.

Baruselli, P. S., Reis, E. L., Marques, M. O., Nasser, L. F., \& Bó, G. A. (2004). The use of hormonal treatments to improve reproductive performance of anestrous beef cattle in tropical climates. Animal Reproduction Science, 82(1), 479-486. doi: 10.1016/j.anireprosci.2004.04.025

Campos, J. T., Morotti, F., Bergamo, L. Z., Costa, C. B., \& Seneda, M. M. (2016a). Pregnancy rate evaluation in lactating and non-lactating Nelore cows subjected to fixed-time artificial insemination using injectable progesterone. Semina: Ciências Agrárias, 37(4), 1991-1996. doi: 10.5433/16790359. 2016v37n4p1991

Campos, J. T., Morotti, F., Costa, C. B., Bergamo, L. Z., \& Seneda, M. M. (2016b). Evaluation of pregnancy rates of Bos indicus cows subjected to different synchronization ovulation protocols using injectable progesterone or an intravaginal device. Semina: Ciências Agrárias, 37(6), 4149-4156. doi: 10.5433/ 1679-0359.2016v37n6p4149

Claro, I., Jr., Sá, O. G., Fo., Peres, R. F. G., Aono, F. H. S., Day, M. L., \& Vasconcelos, J. L. M. (2010). Reproductive performance of prepubertal Bos indicus heifers after progesterone-based treatments. Theriogenology, 74(6), 903-911. doi: 10.1016/j. theriogenology.2010.04.015

Day, M. L., \& Anderson, L. H. (1998). Current concepts on the control of puberty in cattle. Journal of Animal Science, 76(3), 1-15.doi: 10.2527/1998.76suppl_31x
Dias, M. B., F., \& Andrade, C. M. S. (2006). Pastagens no trópico úmido. Belém, PA: EMBRAPA Amazônia Oriental. (EMBRAPA Amazônia Oriental. Documentos, 241). Recuperado de https://www. infoteca.cnptia.embrapa.br/bitstream/doc/378317/1/ Doc241.pdf

Felisbino-Neto, A. R. F., Freitas, B. G., Ramos, R. S., Rezende, M. L. G., Peres, R. F. G., Pozzobon, J.,... Bastos, M. R. (2016). Progesterona injetável pode ser utilizada para indução de ciclicidade em novilhas da raça nelore. Anais da Reunião Anual da Sociedade Brasileira de Embriões, Foz do Iguaçu, PR, Brasil, 20.

Felisbino-Neto, A. R. F., Zanatta, G. M., Fernando, D., Freitas, B. G., Bastos, M. R., Guerreiro, B. M.,... Baruselli, P. S. (2017). Dosagem de progesterona com o sincrogest injetável ${ }^{\circledR}$ na indução de ciclicidade. Anais da Reunião Anual da Sociedade Brasileira de Embriões, Cabo do Agostinho, PE, Brasil, 21

Ferreira, J. P. M., Andrade, J. P. N., Sonnewend, F., Silva, O. R., \& Mello, R. B. (2016). Uso de protocolos hormonais para indução da puberdade em novilhas nelores e seu impacto sobre a taxa de prenhez: relato de caso. Anais da Reunião Anual da Sociedade Brasileira de Tecnologia de Embriões, Foz do Iguaçu, PR, Brasil, 20.

Fike, K. E., Wehrman, M. E., Lindsey, B. R., Bergfeld, E. G., Melvin, E. J., Quintal, J. A.,... Kinder, J. E. (1999). Estrus synchronization of beef cattle with a combination of melengestrol acetate and an injection of progesterone and 17beta-estradiol. Journal of Animal Science, 77(3), 715-723. doi: 10.2527/ 1999.773715x

Funston, R. N., Musgrave, J. A., Meyer, T. L., \& Larson, D. M. (2012). Effect of calving distribution on beef cattle progeny performance. Journal of Animal Science, 90(13), 5118-5121. doi: 10.2527/jas.20125263

Hseuh, A. J. W., Peck, J. R. E. J., \& Clark, J. H. (1976). Control of uterine estrogen receptor levels by progesterone. Endocrinology, 98(2), 438-444. doi: 10.1210 /endo-98-2-438

Instituto Brasileiro de Geografia e Estatística (2017). Produção da Pecuária Municipal 2017. Recuperado de https://biblioteca.ibge.gov.br/visualizacao/ periodicos/84/ppm_2017_v45_br_informativo.pdf

Kinder, J. E., Kojima, F. N., Bergfeld, E. G., Wehrman, M. E., \& Fike, K. E. (1996). Progestin and estrogen regulation of pulsatile $\mathrm{LH}$ release and development of persistent ovarian follicles in cattle. 
Journal of Animal Science, 74(6), 1424-1440. doi: $10.2527 / 1996.7461424 \mathrm{x}$

Lemes, K. M., Maturana-Filho, M., Santin, T., Silva, M. A., Celeghini, E. C. C., \& Madureira, E. H. (2016). Efeito da administração de diferentes fontes de progesterona sobre a indução da puberdade e desempenho reprodutivo em novilhas da raça Nelore. Anais da Reunião Anual da Sociedade Brasileira de Embriões, Foz do Iguaçu, Pr, Brasil, 20.

Lima, R. S. L., Lemes, K. M., Martins, T., \& Madureira, E. H. (2017). Efeito da progesterona injetável de longa ação sobre a indução de puberdade e taxa de prenhez de novilhas Nelore submetidas a IATF. Anais da Reunião Anual da Sociedade Brasileira de Embriões, Cabo do Agostinho, PE, Brasil, 21.

Melo, G. A., Fº, \& Queiroz, H. P. (2011). Gado de corte: o produtor pergunta, a EMBRAPA responde (2a ed. rev. e ampl.). Brasília, DF: EMBRAPA Informação Tecnológica. Recuperado de http://ainfo.cnptia. embrapa.br/digital/bitstream/item/101783/1/500per guntasgadodecorte.pdf

Morotti, F., Campos, J. T., \& Seneda, M. M. (2013b). Fixed-time artificial insemination using injectable progesterone: ovarian follicular dynamics and pregnancy rates of Nelore cows (Bos indicus) with and without a corpus luteum. Semina: Ciências Agrárias, 34(6), 3867-3876. doi: 10.5433/16790359.2013 v34n6Sup12p3867

Morotti, F., Campos, J. T., Lunardelli, P. A., Costa, C. B., Bergamo, L. Z., Barreiros, T. R. R.,... Seneda, M. M. (2018). Injectable progesterone in timed artificial insemination programs in beef cows. Animal Reproduction, 15(1), 17-22. doi: 10.21451/19843143-2017-AR928

Morotti, F., Campos, J. T., Oliveira, E. R., \& Seneda, M. M. (2013a). Ovarian follicular dynamics of Nelore (Bos indicus) cows subjected to a fixed-time artificial insemination protocol with injectable progesterone. Semina: Ciências Agrárias, 34(6), 3859-3866. doi: 10.5433/1679-0359.2013v34n6Supl2 p3859
Nogueira, G. P. (2004). Puberty in South American Bos indicus (Zebu) cattle. Animal Reproduction Science, 82(1), 361-72. doi: 10.1016/j.anireprosci. 2004.04.007

Pavlik, E. J., \& Coulson, P. B. (1976). Modulation of estrogen receptors in four different target tissue: differential effects of estrogen vs. progesterone. Journal of Steroid Biochemistry, 7(5), 369-76. doi: 10.1016/0022-4731(76)90096-0

Pinto, A., Neto, Silva, R. Z., Mota, M. F., \& Alberton, J. (2009). Reutilização de implante intravaginal de progesterona para sincronização de estro em bovinos. Arquivo de Ciência Veterinária e Zoologia -UNIPAR, 12(2), 169-174. doi: 10.25110/arqvet. v12i2.2009.2972

Rhodes, F. M., Burke, C. R., Clark, B. A., Day, M. L., \& MacMillan, K. L. (2002). Effect of treatment with progesterone and estradiol benzoate on ovarian follicular turnover in postpartum anoestrous cows and cows which have resumed estrous cycles. Animal Reproduction Science, 69(3-4), 139-150. doi: 10,1016/ S0378-4320(01)00141-5

Sá, M. F., Fº, Monteiro, B. M., Mendanha, M. F., Souza, A. A., Girotto, R. W., Siqueira, G. R., \& Baruselli, P. S. (2012). Manejo reprodutivo estratégico e IATF em novilhas e vacas primíparas zebuínas de corte. Anais do Simpósio Internacional de Reprodução Animal Aplicada, Londrina, PR, Brasil.

Sá, M. F., Fº, Nasser, L. F. T., Penteado, L., Prestes, R., Marques, M. O., Freitas, B. G.,... Baruselli, P. S. (2015). Impact of progesterone and estradiol treatment before the onset of the breeding period on reproductive performance of Bos indicus beef heifers. Animal Reproduction Science, 160(1), 3039. doi: 10.1016/j.anireprosci.2015.06.024

Ulberg, L. C., \& Lindley, C. E. (1960). Use of progesterone and estrogen in the control of reproductive activities in beef cattle. Journal of Animal Science, 19(4), 1132-1142. doi: $10.2527 /$ jas $1960.1941132 x$ 
